\title{
Grzegorz JANUSZ
}

Uniwersytet Marii Curie-Skłodowskiej w Lublinie

grzegorz.janusz@poczta.umcs.lublin.pl

\section{NAUKI O POLITYCE I ICH USYTUOWANIE W SYSTEMIE NAUK}

\section{ABSTRACT Political science and its' location in the system for sciences}

As the political science has been assigned to new field and domain of social science in 2011 instead of being assigned to humanities, it has caused astonishment and some kind of discomfort in many centres of political science. It was similar to introducing of a new field called public policy science. Assessment of the environment was quiet diverse. As far as by the public policy science one can notice lack of interest, by the new assignment of policy science one can distinguish three contentions: inclusion of the political sciences in the domain of social science, renewed assignment of policy sciences to humanities and assignment of the political sciences to both domains (management studies alike). The third solution is the most supported one in the environment of political scientists. On the same time statements of politicians about reportedly demanded education of welders instead of political scientists and diminished interest with political studies have made the environment of policy analysis anxious. It is to be emphasised that we are not newly formed field of science and any discussions about status of our domain are an ancient history. At the present day staff of the centres of political sciences is outweighed by people, who graduated political studies and their scientific development together with their tittles of professor have been connected with investigations on the field of political studies. This way the environment grows stronger. A few dangers to political science can be pointed out. First of all there is an aspiration to autonomy of some subfields. Second, there is lack of scientific discussion in the environment. Third, there is a western technique of mechanical "scaling", "measuring" and other ways of evaluation of one's academic background, which does not fit to Polish reality and also pervert valuable academic backgrounds. 
Słowa kluczowe: nauki społeczne, nauki o polityce, rozwój nauki, dyskusja naukowa

Keywords: the social science, the political science, scientific development, scientific discussion

\section{STAN PRAWNY}

Cechą charakterystyczną ostatnich lat w zakresie rozwoju nauk w Polsce jest z jednej strony widoczna decentralizacyjna polityka władz państwowych, a z drugiej pojawiające się w poszczególnych dyscyplinach zjawisko autonomizacji subdyscyplin i uzyskania przez nie statusu samodzielnej dyscypliny. Aktualnie usytuowanie nauk o polityce reguluje Rozporządzenie Ministra Nauki i Szkolnictwa Wyższego z dnia 8 sierpnia 2011 r. w sprawie obszarów wiedzy, dziedzin nauki i sztuki oraz dyscyplin naukowych i artystycznych (Dz. U. 2011, nr 179, poz. 1065), w którym umiejscowiono nauki o polityce w nowej dziedzinie nauk społecznych. Była to istotna zmiana, gdyż dotychczasowe regulacje $\mathrm{w}$ tym zakresie umiejscawiały nauki o polityce w dziedzinie nauk humanistycznych. W kolejności chronologicznej po 1990 r., czyli po wejściu w życie odrębnej ustawy o tytule naukowym i stopniach naukowych z 12 września 1990 r., regulowały te kwestie akty niskiej rangi:

1) Obwieszczenie Przewodniczacego Centralnej Komisji do Spraw Tytutu Naukowego i Stopni Naukowych z dnia 25 lutego 1992 r. w sprawie wykazu dziedzin nauki i sztuki oraz dyscyplin naukowych i artystycznych, w zakresie których moga być nadawane stopnie naukowe, M. P. 1992, nr 16, poz. 123,

2) Uchwata Centralnej Komisji do Spraw Stopni i Tytutów z dnia 23 czerwca 2003 r. w sprawie określenia dziedzin nauki i dziedzin sztuki oraz dyscyplin naukowych $i$ artystycznych, M. P. 2003, nr 40, poz. 586,

3) Uchwata Centralnej Komisji do Spraw Stopni i Tytutów z dnia 24 października 2005 r. w sprawie określenia dziedzin nauki i dziedzin sztuki oraz dyscyplin naukowych i artystycznych, M. P. 2005, nr 79, poz. 1120.

Pierwszy akt wewnętrzny Centralnej Komisji do Spraw Stopni i Tytułów nie spełniał dyspozycji ustawowej, gdyż ustawa z 1990 r. o tytule i stopniach wyraźnie uprawnienie w tym zakresie przyznawała nie przewodniczącemu CK, a CK działającej in gremio. Niewłaściwa była także ranga aktu wewnętrznego regulującego tę materię w formie obwieszczenia przewodniczącego, zamiast uchwały $\mathrm{CK}^{1}$. Z kolei w przypadku nowej regulacji z 2003 r. przekazanie uprawnień do regulacji tej materii ze strony CK nie odpowiadało systematyce źródeł prawa w Polsce określonej w art. 87 ust. 1 Konstytucji RP, w której brak uchwał jako źródła powszechnie obowiązującego prawa

Stosowna dyspozycja art. 1 ust. 2 ustawy z 12 IX 1990 r. określała, że Centralna Komisja do Spraw Tytutu Naukowego i Stopni Naukowych, zwana dalej „Centralna Komisja”, określa w formie uchwaty dziedziny nauki i dziedziny sztuki oraz dyscypliny naukowe i artystyczne. 
w Polsce. W efekcie określenie w 2003 r. i 2005 r. dziedzin nauk i dyscyplin naukowych było zgodne z przepisem art. 3 ust. 1 nowej Ustawy z dnia 14 marca 2003 r. o stopniach naukowych i tytule naukowym oraz o stopniach $i$ tytule w zakresie sztuki (Dz. U. 2003, $\mathrm{nr}$ 65, poz. 595), ale niezgodne z regułami legislacji. Stanowiło to oczywiste niechlujstwo legislatora. Podkreślić należy, że zgodnie z istniejącą wcześniej tradycją akty CK umiejscawiały dyscyplinę nauk o polityce w dziedzinie nauk humanistycznych.

Nowa sytuacja zaistniała w przypadku nowelizacji przepisów w drodze Ustawy z dnia 18 marca 2011 r. o zmianie ustawy - Prawo o szkolnictwie wyższym, ustawy o stopniach naukowych i tytule naukowym oraz o stopniach i tytule $w$ zakresie sztuki oraz zmianie niektórych innych ustaw (Dz. U. 2011, nr 84, poz. 455), która prawo do określania dziedzin i dyscyplin naukowych przyznała ministrowi właściwemu do spraw szkolnictwa wyższego, określając jednocześnie rangę aktu. W rozporządzeniu tym dokonano nowej klasyfikacji na obszary wiedzy, dziedziny nauk i dyscypliny nauk. Jednocześnie nauki o polityce zostały przypisane do nowego obszaru i dziedziny nauk społecznych. W większości ośrodków politologicznych taka klasyfikacja nauk o polityce wzbudziła duże zdziwienie oraz pewien dyskomfort. Związane było to także z pojawieniem się w dziedzinie nauk społecznych nowej dyscypliny nauk o polityce publicznej, a także faktem, że nauki o zarządzaniu zostały umiejscowione zarówno w obszarze i dziedzinie nauk humanistycznych, jak i w obszarze nauk społecznych, w dziedzinie nauk ekonomicznych.

\section{KILKA UWAG NATURY HISTORYCZNEJ}

Nauki o polityce są w Polsce dziedziną stosunkowo młodą. Działające we Lwowie i w Krakowie szkoły nauk politycznych sięgają początku XX w. i okresu międzywojennego. Na odbiorze nauk politycznych w społeczeństwie zaciążył okres lat 40. i 50. XX w., kiedy to środowisko nauk politycznych spełniać miało usługową funkcję wobec ówczesnej ideologii, w duchu naukowego komunizmu. Tworzenie na uniwersytetach w latach 60. XX w. jednostek zajmujących się nauką o polityce postrzegane było jako próby przeniesienia poglądów świata zachodniego lub wyłącznie jako transmisja ówczesnej ideologii ${ }^{2}$. Nie sprzyjały temu decyzje władz o wprowadzeniu po wydarzeniach marcowych 1968 r. obowiązkowych lektoratów z podstaw nauk politycznych dla studentów wszystkich kierunków studiów na uczelniach państwowych.

$\mathrm{Z}$ drugiej strony, niezależnie od zamiarów władz, spowodowało to tworzenie na uczelniach jednostek politologicznych, z których część stopniowo odchodziła od zaplanowanej dla nich indoktrynacji i rozwijała badania naukowe. Proces był już wyraźnie widoczny w latach $70 . \mathrm{XX}$ w. W tym czasie podjęto także działania zmierzające do określenia metodologii oraz podstaw teoretycznych nauk o polityce. W okresie swo-

2 Jak wspominał prof. dr hab. Jan Szreniawski, jego inicjatywa utworzenia na Uniwersytecie Mari Curie-Skłodowskiej w Lublinie Studium Nauk Politycznych w 1964 r. (po powrocie ze stypendium z USA) postrzegana była jako próba „przemycania poglądów burżuazyjnych”. O powołaniu Studium zdecydowało stanowisko ówczesnego rektora UMCS prof. Grzegorza Leopolda Seidlera zajmującego się m.in. myślą polityczno-prawną. 
istej odwilży politycznej okresu gierkowskiego w Instytucie Nauk Politycznych Uniwersytetu Warszawskiego rozpoczęto kształcenie na kierunkach politycznych. Wkrótce zaczęły one powstawać na innych uczelniach, ciesząc się rosnącym zainteresowaniem kandydatów. Rozwój jednostek politologicznych jako jednostek dydaktycznych sprzyjał także rozwojowi badań naukowych prowadzonych w obszarach, które wyznaczył często przywoływany kongres ekspertów UNESCO w Paryżu w 1948 r.

\section{POLITOLOGIA CZY NAUKI O POLITYCE}

Dość częstym zjawiskiem jest utożsamianie politologii jako kierunku studiów (dyscypliny dydaktycznej) z naukami o polityce jako dyscypliną naukową. Zresztą przez szereg lat nie budziło to żadnych kontrowersji, gdyż istniała tożsamość nazewnicza między nauką a dydaktyką; studia prowadzono z zakresu nauki o polityce i nauk społecznych, a dyscypliną naukową były nauki o polityce. Trzeba podkreślić, że w latach 80. XX w. pojawiły się dążenia, aby określenie „nauki o polityce” zastąpić określeniem „nauka o polityce”. Wyodrębnianie się z nauk o polityce z dotychczasowych subdyscyplin (w pierwszej kolejności stosunków międzynarodowych) spowodowało już wyraźne rozdzielenie terminologii w zakresie kierunków studiów i dyscypliny naukowej i w latach 90. XX w. wprowadzono jednolite określenie ówczesnego kierunku studiów „nauka o polityce i nauki społeczne”, który uzyskał nową nazwę „politologia”.

To utożsamianie politologii jako dydaktyki i nauk o polityce jako dyscypliny naukowej rodzi określone konsekwencje ${ }^{3}$. Nie unika się tego pomieszania terminów także w naszym środowisku. Książka Ryszarda Skarżyńskiego Podstawowy dylemat politologii: dyscyplina nauki czy potoczna wiedza o spoteczeństwie? jest tego wymownym przykładem, gdyż autor, niezależnie od poruszenia wielu istotnych dla środowiska problemów, nie ustrzegł się przed tym stereotypem - już choćby w tytule. Autor jakby nie chciał dostrzec, że w Polsce nie są nadawane żadne stopnie naukowe z zakresu politologii, a tylko w dyscyplinie nauki o polityce ${ }^{4}$. Co prawda zdecydowanie lepiej brzmi określenie „środowisko politologiczne” czy „politolog” niż „środowisko nauk o polityce”. Zresztą trudno znaleźć odpowiednik określenia „politolog” w obszarze określenia „nauki o polityce”. Stąd też używanie określenia „politolog” jest akceptowalne także w sferze nauki.

Druga przyczyna problemu leży w potocznym utożsamianiu politologii i polityki. Owszem, politolodzy zajmują się także badaniem procesów politycznych, ale cytując Ziemowita Jacka Pietrasia, między politologiem a politykiem jest taka różnica, jak między kryminologiem a kryminalista - obaj zajmują się podobnymi zagadnieniami, ale z catkowicie różnego punktu widzenia. Powiązaniu nauk o polityce z polityką sprzyjają wywiady czy ekspertyzy przedstawicieli naszego środowiska, które w części przypadków są

Np. dziedzina nauk prawnych obejmuje prawo, prawo kanoniczne i administrację, będące także dyscyplinami dydaktycznymi, ale wyraźnie wydzielonymi jako dyscypliny naukowe.

4 Co prawda te kwestie częściowo porusza na stronie 248 i nast. wspomnianej pracy. 
niestety podyktowane nie stanem wiedzy i obiektywną analizą problemu, ale zgodne są z programem i ideologią partii politycznej, z którą utożsamia się osoba wypowiadająca.

Trzecia przyczyna leży w eksplozji kierunku studiów politologicznych po 1990 r., kiedy to w wielu uczelniach tworzono politologię. Kierunek ten powstawał nie tylko na uczelniach prywatnych, ale także na uczelniach technicznych. Liczba powstałych kierunków nie znajdowała oparcia kadrowego w środowisku politologicznym. W efekcie wiele kierunków studiów politologicznych, a także w zakresie stosunków międzynarodowych czy europeistyki tworzonych było z udziałem historyków, socjologów, filozofów, a nawet specjalistów spoza nauk humanistycznych ${ }^{5}$. Te praktyki eliminowane były stopniowo po powstaniu w 2002 r. Państwowej Komisji Akredytacyjnej. Efektem było pojawienie się w środowisku wielu osób, które określały się jako politolodzy, mimo że nie prowadziły żadnych badań w zakresie nauk o polityce i nie funkcjonowały w środowisku politologicznym. Jednocześnie w wyniku nadmiaru tworzonych kierunków studiów nastąpiło obniżenie prestiżu politologii jako dyscypliny dydaktycznej. Wzmacniały to niefortunne wypowiedzi niektórych polityków o pożądanym jakoby „kształceniu spawaczy zamiast politologów" - tak jakby uczelnie odpowiadały za stan gospodarki państwa, a nie za kształcenie.

Kolejnym problemem było zniesienie standardów kształcenia (dawnych minimów programowych) oraz wykazu kierunków i powstawanie nowych kierunków studiów. W efekcie istnieje duża dowolność w określaniu nowych kierunków studiów - zresztą ze szkodą dla politologii, która staje się coraz bardziej niszowym kierunkiem. Na szczęście uniwersyteckie ośrodki politologiczne zachowują w zakresie politologii dawne minima programowe decydujące o tożsamości kierunku studiów.

Wreszcie obszar nauk o polityce staje się atrakcyjny z różnych przyczyn dla specjalistów z innych dyscyplin. Przyjęli oni z dużym zadowoleniem utworzenie nowej dyscypliny naukowej, w znacznym stopniu obejmującej obszar badawczy nauk o polityce, jaką stały się nauki o polityce publicznej. Zresztą główny orędownik powołania tej dyscypliny, reprezentujący nauki techniczne, nie widział niczego niestosownego w powołaniu go przez Centralną Komisję na recenzenta rozprawy habilitacyjnej w dyscyplinie nauk o polityce. Przy okazji rozwoju naukowego rację ma Ryszard Skarżyński, że wiele osób, które nie czują się na siłach, aby starać się o uzyskanie stopnia naukowego w innych dyscyplinach, próbuje w tej sytuacji wszcząć procedurę w zakresie nauk o polityce, i niestety przy akceptacji lub bierności środowiska udaje się im w wielu przypadkach ten stopień uzyskać. . Co prawda, nie jest to bolączka tylko naszej dyscypliny, gdyż można tu podać wiele przykładów słabych doktoratów czy innych prac na stopień lub tytuł w innych dyscyplinach - można choćby wspomnieć głośne kontrowersje wokół,

\footnotetext{
Wymownym tego przykładem był wniosek jednej z uczelni w sprawie utworzenia politologii, gdzie wśród kadry wykazano profesora nauk rolniczych, który miał prowadzić politologiczny przedmiot „polityka hodowli trzody chlewnej w Polsce” (???). W innym przypadku wskazano matematyka czy inżyniera budownictwa jako specjalistów politologicznych prowadzących określony przedmiot w obszarze własnych badań uzupełniony o słowo „polityka”.

$6 \quad$ R. Skarzyński, Podstawowy dylemat politologii: dyscyplina nauki czy potoczna wiedza o spoteczeństwie? O tradycji uniwersytetu i demarkacji wiedzy, Białystok 2012, m.in. s. 206 i nast.
} 
podobno zdaniem recenzentów „wyśmienitego i nowatorskiego”, doktoratu $w d z i e d z i$ nie nauk ekonomicznych prezesa Business Centre Club. Wielokrotnie jako dziekan rozmawiałem z potencjalnymi kandydatami do rozwoju naukowego i wszczęcia procedury na naszym wydziale, reprezentującymi inne dyscypliny, którzy uważali, że dodanie do tytułu rozprawy słowa „polityka” lub „polityczny” będzie właściwe dla kwalifikacji tej rozprawy w obszarze nauk o polityce. Ich zdziwienie budziła sugestia realizacji postępowania w innej dyscyplinie, gdyż temat, struktura pracy czy metodologia były właściwe dla innych dyscyplin, np. dla historii.

Co prawda czasami powstaje pytanie, w którym miejscu kończy się interdyscyplinarność nauk o polityce, która legła u podstaw jej rozwoju, a w którym miejscu mamy do czynienia z tematyką z innej dyscypliny? Rację jednak ma Karol Boromeusz Janowski w swoim mailu do środowiska, że właściwe dyskusje o tożsamości i statusie dyscypliny mamy już dawno za sobą, a nauki o polityce nie powstały dopiero w 1989 r., gdyż dorobek politologiczny wielu znamienitych przedstawicieli naszego środowiska powstawał w całym XX w. ${ }^{7}$ a dzisiejsze pokolenie politologów to często wychowankowie osób, których dorobek i nazwiska są czasami pomijane. Nie ulega przy tym wątpliwości, że nauki o polityce wyszły już dawno z pierwotnego stadium, w którym ich rozwój związany był $\mathrm{z}$ dorobkiem innych dyscyplin (głównie prawa i historii); pierwsze habilitacje z zakresu nauk o polityce realizowane były jeszcze w latach 70 . XX w., aczkolwiek stopień doktora habilitowanego uzyskiwały osoby, które kończyły niepolitologiczne kierunki studiów, a stopień naukowy doktora uzyskiwały w innych dyscyplinach. Dzisiaj wśród kadry ośrodków politologicznych przeważają osoby, które ukończyły politologię, a ich rozwój naukowy, łącznie z uzyskaniem tytułu naukowego profesora, związany był z badaniami w obszarze nauk o polityce ${ }^{8}$. Tworzy to już nową jakość w naszej dyscyplinie.

\section{NAUKI O POLITYCE - DZIEDZINA NAUK SPOŁECZNYCH CZY NAUK HUMANISTYCZNYCH?}

Jak zaznaczono, nowa klasyfikacja nauk o polityce z 2011 r. nie wzbudziła entuzjazmu w środowisku. $\mathrm{Z}$ tego powodu część ośrodków politologicznych skorzystała z dwuletniego vacatio legis i wniosek o zakwalifikowanie posiadanych uprawnień do nowej dziedziny składała dopiero w 2013 r. Trzeba podkreślić, że zmiana przyporządkowania nauk o polityce do nowej dziedziny nie była przedmiotem dyskusji w środowisku i została podjęta arbitralnie. Metodologia nauk o polityce opiera się przede wszystkim na metodologii nauk humanistycznych. Wykorzystywane są oczywiście również metody $\mathrm{z}$ innych nauk, m.in. prawa, pojawiają się także metody lub techniki badawcze właści-

K.B. Janowski, Glosa dot. listów środowiska politologicznego. Refleksje osobiste, 8 VI 2015 (mail z 16 VI 2015 r.).

8 Nadal jednak przy konkursach przeprowadzanych na Wydziale Politologii UMCS, gdzie warunkiem jest legitymowanie się stopniem doktora lub doktora habilitowanego w dyscyplinie nauki o polityce, wpływają podania od przedstawicieli innych dyscyplin i takie jednoznaczne ograniczenie budzi wśród tej części kandydatów duże zdziwienie. 
we tylko dla nauk o polityce. Co prawda oczekiwanie, że każda rozprawa habilitacyjna w dyscyplinie nauk o polityce wniesie nową jakość metodologiczną, jest chyba nieporozumieniem, gdyż przy liczbie kilkudziesięciu rozpraw habilitacyjnych w zakresie nauk o polityce rocznie (a w poszczególnych latach ich liczba bywała też większa) oczekiwanie wniesienia przez każdą z nich nowych metod czy technik badawczych jest oczywiście wręcz niemożliwe.

W związku z pojawiającymi się czasami zastrzeżeniami, że przeciwnikami nowego przyporządkowania nauk o polityce są osoby, których rozwój naukowy związany był z innymi dyscyplinami, przeprowadziłem wśród pracowników Wydziału Politologii UMCS krótką ankietę w tej sprawie polegającą na udzieleniu odpowiedzi odnośnie do przyporządkowania dyscypliny. Należy przy tym podkreślić, że sugestie ze strony środowiska odnoszą się przede wszystkim nie do zmiany przyporządkowania dyscypliny (z dziedziny nauk społecznych na dziedzinę nauk humanistycznych), ale zastosowania identycznego rozwiązania, jakie w przedmiotowym rozporządzeniu zastosowano wobec nauk o zarządzaniu, które zostały umiejscowione zarówno w obszarze i dziedzinie nauk humanistycznych, jak i w obszarze nauk społecznych, w dziedzinie nauk ekonomicznych. W tej sytuacji istnieje już rozwiązanie precedensowe, które mogłoby być zastosowane wobec nauk o polityce. Trzeba podkreślić, że takie rozwiązanie nie ma charakteru obligatoryjnego, a stwarza możliwość uprawnionej jednostce do pozostania $\mathrm{w}$ jednej dyscyplinie lub posiadania uprawnień w obu obszarach.

Wspomniana ankieta skierowana została do 102 pracowników Wydziału Politologii UMCS. Odpowiedzi na nią udzieliło 50 pracowników legitymujących się co najmniej stopniem naukowym doktora. Spośród nich 38 osób posiada nadany stopień doktora w dyscyplinie nauk o polityce, w tym 28 osób w dziedzinie nauk humanistycznych, a $10 \mathrm{w}$ dziedzinie nauk społecznych. Ponadto w dziedzinie nauk humanistycznych, ale w innej dyscyplinie (głównie z zakresu historii) stopnie doktora uzyskało 11 osób, a 1 osoba uzyskała stopień doktora w innej dziedzinie niż wyżej wymienione. W'śród nich grupę tzw. samodzielnych pracowników naukowych (co najmniej ze stopniem doktora habilitowanego) reprezentowało 15 osób.

W zakresie przyporządkowania nauk o polityce uzyskano następujące wypowiedzi: 28 osób opowiedziało się za przyporządkowaniem dyscypliny do obu dziedzin (w tym 12 tzw. samodzielnych pracowników naukowych), 11 osób opowiedziało się za przyporządkowaniem dyscypliny wyłącznie do dziedziny nauk humanistycznych, 10 osób opowiedziało się za przyporządkowaniem dyscypliny wyłącznie do dziedziny nauk społecznych, 1 osoba nie miała zdania w sprawie.

Jak wynika z powyższego, nie ma jednomyślności w mikrośrodowisku, jakie tworzy społeczność wydziału, aczkolwiek zdecydowanie większe poparcie ma rozwiązanie polegające na przyporządkowaniu nauk o polityce do obu dziedzin. Dość charakterystyczne, że w grupie 10 osób, które stopień doktora w dyscyplinie nauk o polityce uzyskały już w dziedzinie nauk społecznych, tylko 3 osoby były za wyłącznym przyporządkowaniem dyscypliny do dziedziny nauk społecznych, a 4 za przyporządkowaniem do dziedziny nauk humanistycznych. Również 3 osoby opowiedziały się za przyporządkowaniem do obu dziedzin. W grupie 4 doktorów habilitowanych, którzy uzyskali już 
stopnie w dziedzinie nauk społecznych, 2 osoby opowiedziały się za przyporządkowaniem do dziedziny nauk humanistycznych, 1 osoba do dziedziny nauk społecznych i 1 osoba za przyporządkowaniem do obu dziedzin. Można przypuszczać, że podobne zróżnicowanie stanowisk występuje w innych ośrodkach politologicznych.

Część osób uzasadniła swoje stanowisko w sprawie. Generalnie były one zbliżone $\mathrm{w}$ treści i odnosily się do usytuowania nauk o polityce w obu dziedzinach. Zwracano uwagę m.in. na to, że nauki o polityce, biorąc pod uwagę istotę polityki (sensu largo), musza mieć charakter interdyscyplinarny. Co oznacza konieczność wykorzystania zarówno dorobku, jak i siatki pojęciowej oraz metodologii wielu dyscyplin - prawa, historii, medioznawstwa, filozofii, religioznawstwa, antropologii kultury, ekonomii, jezykoznawstwa etc. - a zatem dyscyplin zaliczajacych się tak do nauk spotecznych, jak i humanistycznych, czy też na to, że nauki o polityce maja bardzo heterogeniczny przedmiot badań, jego (możliwie) petnej analizie sprzyja zróżnicowane, interdyscyplinarne instrumentarium badawcze: nauki humanistyczne umożliwiaja uprawianie filozofii polityki i zapewniaja ugruntowane metodologie analizy (szeroko rozumianej) zawartości; nauki spoteczne oferuja socjologię aktorów spotecznych (politycznych) i tradycje analizy systemowej.

W jednej z wypowiedzi podkreślono niebezpieczeństwo, jakie niesie dążenie subdyscyplin (m.in. stosunków międzynarodowych, europeistyki, marketingu politycznego) do autonomizacji i powstania samodzielnej dyscypliny naukowej - co niezależnie od przyporządkowania nauk o polityce wpłynęłoby na ich osłabienie. Jest to rzeczywisty problem, przed którym stoją nauki o polityce obejmujące politologię, stosunki międzynarodowe, europeistykę, marketing polityczny, dziennikarstwo i komunikację społeczną (do niedawna), a także wiele innych tworzonych ostatnio nowych kierunków studiów.

Opowiadając się za przyporządkowaniem nauk o polityce do obu dziedzin, w zjawisku autonomizacji subdyscyplin, widzę większy problem niż w przyporządkowaniu dyscypliny.

Drugie zagrożenie widzę w braku dyskusji naukowej w środowisku - jeśli się ona pojawia, to tylko w formie mało efektywnej, by nie rzecz pozorowanej. Uczestnicząc od wielu lat w różnych konferencjach naukowych, obserwuję zjawisko zaniku dyskusji nad problemem; dzisiaj o jakości konferencji decyduje liczba referatów i nazwiska referentów. Liczba wystąpień jest tak duża, że uwzględnienie (o ile ma to miejsce) łącznie kilkunastu minut na dyskusję po wszystkich wystąpieniach nie daje żadnej możliwości wymiany poglądów. Dzisiejsze konferencje przypominają monolog referenta, który często pojawia się na konferencji nie po to, aby w niej uczestniczyć, ale wygłosić swój referat, a następnie opuszcza obrady. Ta maniera pojawiła się w ostatnich latach i przenosi się także na dyskusję (nie chcę iść za daleko i mówić nawet o sporze naukowym) w środowisku, która właściwie nie istnieje, a przedstawienie przeciwnego lub krytycznego poglądu jest traktowane jako obraza czyjejś pozycji naukowej. Brak jest też krytycznych recenzji ukazujących się w środowisku publikacji. Mając na uwadze, że o rozwoju nauki decyduje dysputa naukowa, a także spór naukowy, to osłabienie takiej dyskusji, a w dużej części jej brak w środowisku stanowi moim zdaniem rzeczywiste wyzwanie dla nauk o polityce.

Trzeci problem to wzorowana na rozwiązaniach zachodnich i niedostosowana do realiów polskich oraz nauk społecznych (humanistycznych) idea i praktyka mechanicz- 
nego „ważenia”, „mierzenia” czy innego oceniania dorobku, które wypaczają w dużej części uznany dorobek naukowy. Warto powiedzieć, że w obszarze nauk humanistycznych czy społecznych wielu znamienitych badaczy, twórców dyscyplin, nie znalazłoby się w rankingach opartych o nie zawsze przejrzyste kryteria. Co prawda znajomy chemik stwierdził, że Maria Skłodowska-Curie też nie miałaby szans na pozyskanie dzisiaj grantu badawczego, ale nie zmienia to faktu, że szukając złotego środka oceny dorobku, uczyniono to zbyt mechanicznie, a dzisiaj bardziej niż jakość publikacji liczy się jej umiejscowienie wydawnicze, a najlepiej jeszcze wydanie w języku angielskim - choćby w słabym wydawnictwie. W efekcie w czasie jednej z parametryzacji na czołowym miejscu znalazła się w naszej dyscyplinie mała uczelnia prywatna publikująca prace swoich pracowników wyłącznie w języku angielskim i we własnym wydawnictwie. To, że nie miały one żadnego wpływu na badania w zakresie nauk o polityce, dla oceniających nie miało już chyba żadnego znaczenia.

\section{BIBLIOGRAFIA}

Janowski K.B., Glosa dot. listów środowiska politologicznego. Refleksje osobiste, 8 VI 2015 (mail z 16 VI 2015 r.).

Obwieszczenie Przewodniczacego Centralnej Komisji do Spraw Tytutu Naukowego i Stopni Naukowych $z$ dnia 25 lutego $1992 \mathrm{r}$. w sprawie wykazu dziedzin nauki i sztuki oraz dyscyplin naukowych $i$ artystycznych, w zakresie których moga być nadawane stopnie naukowe, M. P. 1992, nr 16, poz. 123.

Rozporzadzenie Ministra Nauki i Szkolnictwa Wyższego z dnia 8 sierpnia 2011 r. w sprawie obszarów wiedzy, dziedzin nauki i sztuki oraz dyscyplin naukowych i artystycznych, Dz. U. 2011, nr 179, poz. 1065.

Skarzyński R., Podstawowy dylemat politologii: dyscyplina nauki czy potoczna wiedza o spoteczeństwie? O tradycji uniwersytetu i demarkacji wiedzy, Białystok 2012.

Uchwata Centralnej Komisji do Spraw Stopni i Tytutów z dnia 23 czerwca 2003 r. w sprawie określenia dziedzin nauki i dziedzin sztuki oraz dyscyplin naukowych i artystycznych, M. P. 2003, nr 40, poz. 586.

Uchwata Centralnej Komisji do Spraw Stopni i Tytutów z dnia 24 października 2005 r. w sprawie określenia dziedzin nauki i dziedzin sztuki oraz dyscyplin naukowych i artystycznych, M. P. 2005, $\mathrm{nr} 79$, poz. 1120.

Ustawa $z$ dnia 14 marca 2003 r. o stopniach naukowych i tytule naukowym oraz o stopniach i tytule w zakresie sztuki, Dz. U. 2003, nr 65, poz. 595.

Ustawa z dnia 18 marca 2011 r. o zmianie ustawy - Prawo o szkolnictwie wyzszym, ustawy o stopniach naukowych i tytule naukowym oraz o stopniach i tytule $w$ zakresie sztuki oraz zmianie niektórych innych ustaw, Dz. U.2011, nr 84, poz. 455.

Prof. dr hab. Grzegorz JANUSZ - prof. zw., prodziekan Wydziału Politologii UMCS (Instytutu Nauk Politycznych) (1987-1993), dziekan Wydziału Politologii UMCS (2008-2016), kierownik Zakładu Praw Człowieka. 